\title{
Penerapan Text Mining dalam Spam Filtering untuk Aplikasi Chat
}

\author{
Ni Luh Ratniasih ${ }^{1}$, Made Sudarma ${ }^{2}$, Nyoman Gunantara ${ }^{3}$
}

\begin{abstract}
The Internet has become something important in the communication development. One communication facilities on the Internet is the Internet relay chat or known as chat. Chat applications in real time is often misused for the purpose of spreading the virus, promotions, and other interests known as spam. Spamming is the sending of unwanted messages by someone who has a chat account. This causes the chat account feel uncomfortable with the condition. Based on these problems this research create a chat application that can filter messages or spam filtering by applying text mining. Spam filtering process can be done in two phases: text pre-processing and analyzing. These two phases are carried out to calculate the weight $(W)$ of connectedness with the word spam messages. Based on the results of tests performed on chat applications by applying text mining to perform filtering on spam messages generate the level of accuracy of $91.41 \%$.

Intisari - Internet telah menjadi sesuatu hal yang penting dalam perkembangan sarana komunikasi. Salah satu fasilitas komunikasi yang terdapat pada internet adalah internet relay chat atau yang sering dikenal dengan istilah chat. Aplikasi chat yang bersifat real time sering disalahgunakan untuk keperluan penyebaran virus, promosi, dan kepentingan lain yang dikenal dengan istilah spam. Tindakan spamming adalah pengiriman pesan yang tidak diinginkan oleh seseorang yang memiliki sebuah akun chat. Hal ini menyebabkan pemilik akun merasa tidak nyaman dengan kondisi tersebut. Berdasarkan permasalah tersebut maka dalam penelitian ini membuat sebuah aplikasi chat yang dapat menyaring pesan atau spam filtering dengan menerapkan text mining. Proses spam filtering dilakukan dengan dua tahap yaitu tahap text preprocessing dan analyzing. Kedua tahap ini dilakukan untuk menghitung bobot $(W)$ keterhubungan kata spam dengan pesan. Berdasarkan hasil pengujian yang dilakukan pada aplikasi chat dengan menerapkan text mining untuk melakukan filtering terhadap pesan spam menghasilkan tingkat akurasi sebesar $91.41 \%$.
\end{abstract}

Kata Kunci-Aplikasi Chat, Text Mining, Spam filtering..

\section{PENDAHULUAN}

Internet Relay Chat atau yang sering dikenal dengan istilah chat, merupakan sumber daya dalam internet yang memungkinkan dua orang atau lebih (group) melakukan dialog secara langsung dan real time dalam bentuk komunikasi yang tertulis [1]. Berbagai penelitian pun dilakukan untuk mengembangkan aplikasi chat itu sendiri

\footnotetext{
${ }^{1}$ Mahasiswa Magister Teknik Elektro Universitas Udayana Kampus Jl. PB Sudirman Denpasar; e-mail ratni.3112@yahoo.com

2,3 Dosen Teknik Elektro Fakultas Teknik Universitas Udayana, Jalan Kampus Bukit Jimbaran 80361 INDONESIA (telp: 0361-703315; fax: 0361-4321; e-mail: msudarma@unud..ac.id, gunantara@unud.ac.id
}

seperti penelitian yang dilakukan oleh Diny Wahyuni yaitu pengembangan aplikasi pertukaran pesan berbasis teks melalui jaringan lokal (LAN) menggunakan Microsoft Visual C++6.0 [2]. Aplikasi chat yang bersifat real time sering disalahgunakan untuk keperluan spam oleh beberapa orang, dimana mereka akan mengirimkan pesan yang tidak diinginkan oleh pemilik akun chat untuk berbagai tujuan mulai dari marketing sampai dengan merusak sistem dan mencuri informasi dari komputer korban yang memilih sebuah link dalam pesan sampah tersebut.

Berbagai cara dan aplikasi telah digunakan untuk mengatasi masalah spam yang bermula dari masalah email spam sampai dengan SMS spam. Jose Maria Gomez, dkk., melakukan penelitian mengenai spam filtering pada SMS dengan menggunakan metode Bayessian Filtering yang dipublikasikan pada sebuah jurnal yang berjudul Content Based SMS Spam Filtering [3]. Mereka mencoba menggunakan Bayesian Filters yang terbukti efektif dalam penanganan spam email. Penelitian dilakukan dengan menggunakan koleksi spam untuk SMS dalam dua bahasa yaitu Inggris dan Spanyol. Hasilnya, Bayesian Filtering juga efektif jika diterapkan untuk SMS spam.

Pada penelitian ini akan dirancang sebuah aplikasi chat yang mampu menyaring spam dengan menggunakan text mining dan teknik Challenge-response filtering. Rumusan masalah utama dalam penelitian ini adalah mengetahui pola kalimat pesan yang dinyatakan spam serta tingkat akurasi dan response time dari sistem filtering spam dalam mengklasifikasikan pesan ke dalam kelompok spam dan non spam. Bahasa teks pesan yang digunakan sebagai data training dan data testing adalah bahasa Inggris.

\section{METODE PENELITIAN}

\section{A. Asitektur Umum Sistem.}

Arsitektur sistem menggambarkan kerja sistem pada proses analisa dan implementasi, dimana arsitektur sistem dari penelitian ini ditunjukkan pada Gambar 1. Tahap pertama dimulai dari pre-processing koleksi pesan yang dimulai dari proses tokenizing, penghapusan stop-words, diakhiri dengan proses stemming.

Tahap kedua adalah pengklasifikasian dokumen yang dimulai dari analyzing yaitu penghitungan bobot dari proses pre-processing sehingga diperoleh nilai pembobotan. Dari nilai pembobotan dilakukan klasifikasi terhadap data testing. Tahap terakhir dari sistem ini yaitu menghitung prosentase ketepatan (akurasi) sistem. Untuk menghitung akurasi sistem dalam mengklasifikasikan data testing digunakan teori confusion matrix yaitu dengan menentukan berapa nilai TP, TN, FP dan FN kemudian dihitung dengan menggunakan persamaan (1) berikut ini [4] : 
Akurasi $=\frac{T P+T N}{T P+F N+F P+T N} * 100 \%$

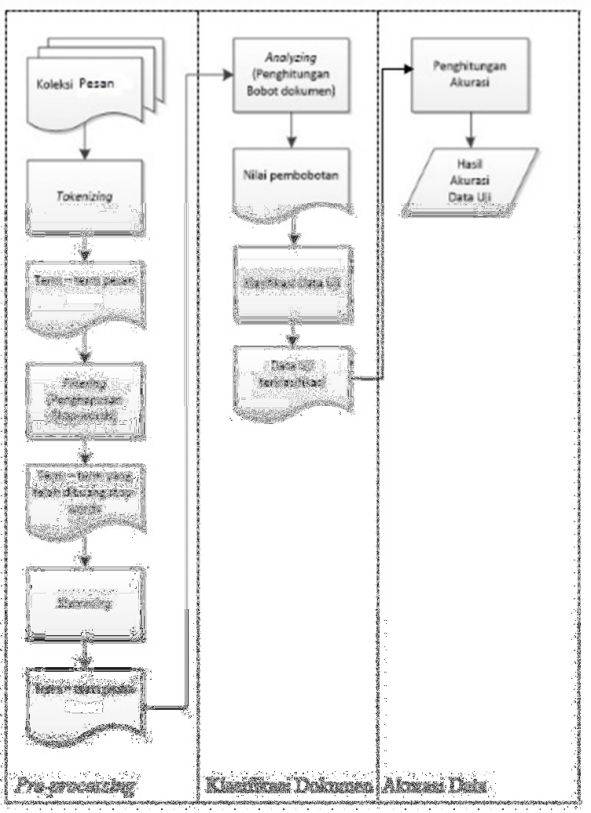

Gambar 1: Arsitektur Sistem

\section{B. Data Penelitian}

Data yang digunakan dalam penelitian ini adalah data primer dan data sekunder. Data sekunder diperoleh atau dikumpulkan dari berbagai sumber yang telah ada yaitu dari halaman website yang menyediakan spam archive yaitu http://untroubled.org/spam/ dan http://www.dt.fee.unicamp.br. Link tersebut merupakan situs yang khusus mengarsip kalimat spam dan non spam. Sedangkan data primer diperoleh atau dikumpulkan secara langsung atau mandiri.

Jumlah data pesan yang digunakan dalam penelitian adalah sebanyak 1748 data (dalam bentuk kalimat pesan). Terdapat 5 contoh data pesan seperti pada Tabel 1. Di dalam tabel terdapat 4 pesan yang merupakan pesan non spam yaitu pesan nomer 1, 2, 4, dan 5 pesan yang merupakan pesan spam yaitu pesan nomer 3. Pesan spam adalah pesan yang memberikan informasi tertentu yang bersifat komersil atau pesan yang menyampaikan hadiah.

TABEL I

CONTOH KATEGORI PESAN

\begin{tabular}{|c|l|c|}
\hline No & \multicolumn{1}{|c|}{ Pesan } & Kategori \\
\hline 1. & Ok lar... Joking wif u oni... & Non Spam \\
\hline 2. & $\begin{array}{l}\text { U dun say so early hor... U c already then } \\
\text { say... }\end{array}$ & Non Spam \\
\hline 3. & $\begin{array}{l}\text { Go until jurong point, crazy.. Available } \\
\text { only in bugis } n \text { great world la e buffet... } \\
\text { Cine there got amore wat... }\end{array}$ & Non Spam \\
\hline 4. & $\begin{array}{l}\text { Nah I don't think he goes to usf, he lives } \\
\text { around here though }\end{array}$ & Non Spam \\
\hline 5. & $\begin{array}{l}\text { Free entry in 2 a wkly comp to win FA } \\
\text { Cup final tkts 21 st May 2005. Text FA to } \\
\text { 87121 to receive entry question(std txt } \\
\text { rate)T\&C's apply 08452810075over18's }\end{array}$ & Spam \\
\hline
\end{tabular}

ISSN $1693-2951$
Dari seluruh data yang digunakan, data akan dibagi menjadi dua yaitu $70 \%$ sebagai data training (data latih) dan 30\% sebagai data testing (data uji). Data training merupakan data yang digunakan dalam melakukan pembelajaran sedangkan data testing adalah data yang tidak pernah dipakai sebagai pembelajaran dan akan berfungsi sebagai data pengujian kebenaran atau keakurasian hasil pembelajaran [5]. Berdasarkan hasil penelitian yang dilakukan oleh Yushintia Pramitarini, dkk dalam mengklasifkasikan status gizi anal balita menggunakan Naive Bayes Classifier (NBC) membuktikan bahwa persentase (\%) akurasi sistem paling tinggi dihasilkan dengan perbandingan jumlah data training dan data testing adalah $70 \%$ dan $30 \%$ [6]. Sehingga jumlah data yang digunakan sebagai data training adalah 1224 kalimat pesan dan data testing adalah 524 kalimat pesan.

\section{Text Mining}

Text mining merupakan salah satu teknik yang dapat digunakan untuk melakukan klasifikasi, dimana text mining merupakan variasi dari data mining yang berusaha menemukan pola yang menarik dari sekumpulan data tekstual yang berjumlah besar [7]. Dalam penerapan text mining, terdapat beberapa langkah yang perlu dilakukan antara lain :

\section{a) Tokenizing}

Tokenizing merupakan proses penguraian deskripsi yang semula berupa kalimat menjadi kata [8]. Contoh proses tokenizing pada sebuah kalimat dapat dilihat pada Tabel 2.

TABEL II

TAHAP TOKENIZING

\begin{tabular}{|l|l|}
\hline \multicolumn{1}{|c|}{ Text Input } & \multicolumn{1}{c|}{ Hasil Token } \\
\hline Go until jurong point, crazy.. & go \\
Available only in bugis n & until \\
great world la e buffet... Cine & jurong \\
there got amore wat... & point \\
& crazy \\
& available \\
& $\ldots$ \\
& wat \\
\hline
\end{tabular}

Semua kata yang menyusun kalimat pada kolom "Text Input" dipotong berdasarkan kata yang menyusunnya seperti terlihat di kolom "Hasil Token" pada Tabel 2.

\section{b) Filtering}

Filtering adalah tahap mengambil kata penting dari hasil proses token. Bisa menggunakan algoritma stop list atau word list [9]. Filtering dapat juga diartikan sebagai proses mengambil kata - kata penting dari hasil proses token atau penghapusan stopwords. Stopwords merupakan kosa kata yang bukan merupakan ciri (kata unik) dari suatu dokumen [10]. Untuk contoh tahap filtering terlihat pada Tabel 3.

Kolom "Hasil Token" pada Tabel 3 adalah kata - kata yang berasal dari proses tokenizing sedangkan kata yang berada pada kolom "Hasil Filtering" adalah hasil setelah proses filtering yaitu menghilangkan kata yang tidak penting seperti kata penghubung "go", "in", dan "there".

Ni Luh Ratniasih: Penerapan Text Mining dalam ... 
TABEL III

TAHAP FILTERING

\begin{tabular}{|l|l|}
\hline \multicolumn{1}{|c|}{ Hasil Token } & \multicolumn{1}{c|}{ Hasil Filtering } \\
\hline go & until \\
until & jurong \\
jurong & point \\
point & crazy \\
crazy & available \\
available & bugis \\
in & \\
bugis & \\
$\ldots$ & $\ldots$ \\
wat & wat \\
\hline
\end{tabular}

\section{c) Stemming}

Stemming merupakan tahap untuk mencari root kata dari hasil filtering. Stemming adalah proses pemetaan dan penguraian berbagai bentuk (variants) dari suatu kata menjadi bentuk kata dasarnya (stem) [11]. Hasil proses stemming data training dapat dilihat pada Gambar 2.

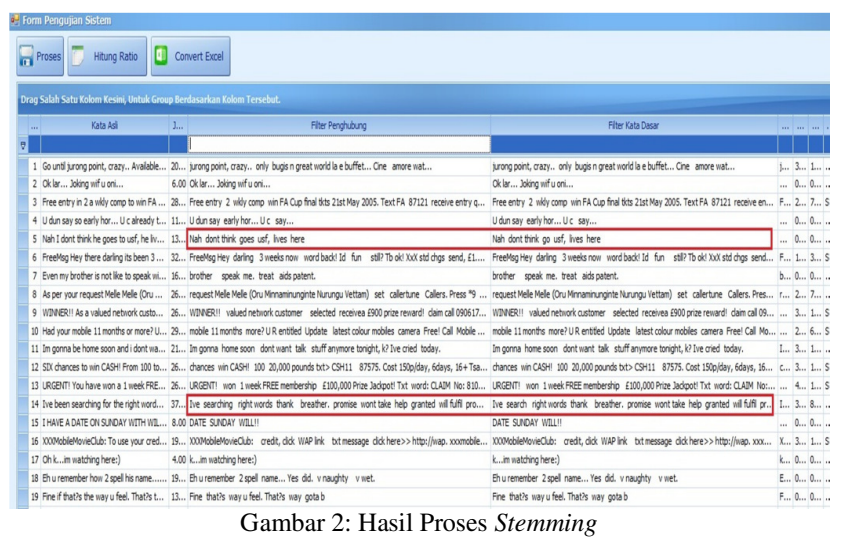

Pada kalimat dengan ID 5 terdapat kalimat hasil proses filtering yaitu "Nah don't think goes usf, lives here", setelah adanya proses stemming kata "goes" berubah menjadi "go".

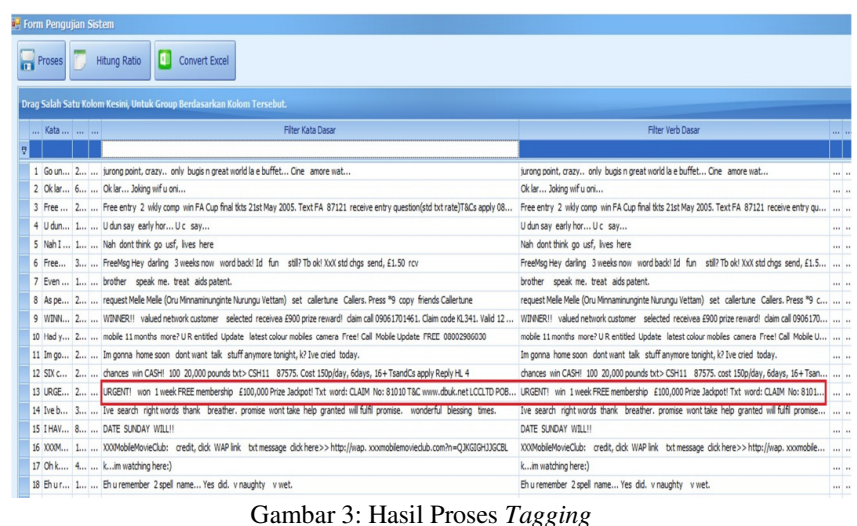

Gambar 3: Hasil Proses Tagging d). Tagging

Tagging merupakan tahap untuk mencari bentuk awal/root dari tiap kata lampau atau hasil dari proses stemming. Hasil proses tagging sistem terhadap pesan terlihat pada Gambar 3. Terdapat beberapa kata lampau yang dikembalikan ke bentuk awal, misalkan pada data pesan dengan ID 13 terdapat kata "won" dirubah ke bentuk awal menjadi "win".

\section{e). Tahap Analysing}

Analyzing merupakan tahap penentuan seberapa jauh keterhubungan antar suatu kata atau term terhadap suatu dokumen atau kalimat dengan menghitung nilai/bobot keterhubungan. Algoritma TF/IDF digunakan dalam proses perhitungan bobot $(W)$ terminologi kata. Algoritma ini digunakan untuk menghitung bobot setiap kata yang paling umum digunakan pada information retrieval. Metode ini juga terkenal efisien, mudah dan memiliki hasil yang akurat [12].

Persamaan yang digunakan untuk menghitung bobot $(W)$ masing - masing dokumen terhadap kata kunci adalah [12] :

$$
\begin{gathered}
W_{d, t}=t f_{d, t} * I D F \\
\text { dimana: } \begin{aligned}
W & =\text { bobot dokumen ke }-n \\
d & =\text { dokumen } \\
t & =\text { kata kunci } \\
t f & =\text { terms frequency (jumlah kemunculan kata) } \\
I D F & =\text { Inverse Document Frequency }
\end{aligned}
\end{gathered}
$$

Nilai $t f$ diperoleh dari [12] :

$t f_{d}=\frac{\text { Jumlah munculnya kata } t \text { dalam dokumen }}{\text { Total jumlah seluruh kata dalam dokumen }}$

Nilai $I D F$ didapatkan dari [12]:

$I D F=\log _{2}\left(\frac{D}{d f}\right)$

dimana $: D=$ total dokumen, dalam hal ini total kalimat yang ada.

$d f=$ jumlah dokumen yang mengandung kata kunci.

\section{HASIL DAN PEMBAHASAN}

Untuk melakukan kegiatan chatting melalui sistem aplikasi ini, hal pertama yang harus dilakukan adalah menjalankan server agar client atau user dapat terkoneksi ke server dan user dapat melakukan kegiatan chatting. 


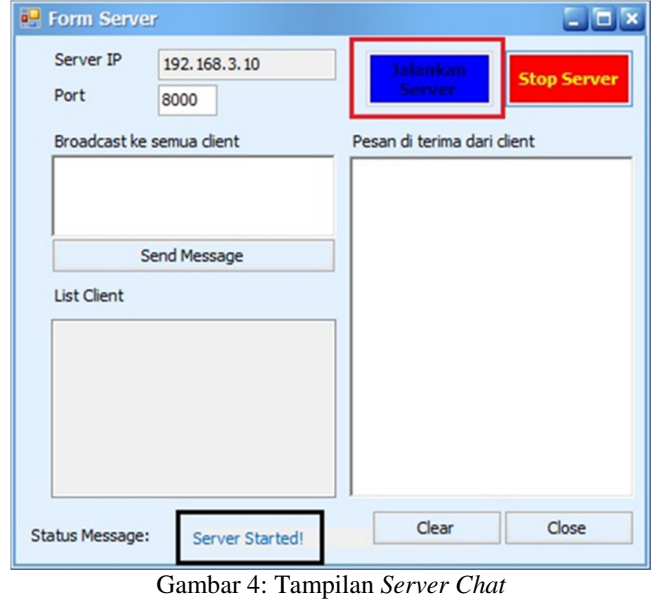

Jika server terkoneksi maka statusnya akan menjadi "Server Started!" seperti yang terlihat pada Gambar 4. Perlu dicatat adalah IP Address server, LAN card pada komputer harus berisi IP Address terlebih dahulu, dan Port yang digunakan adalah port bebas dan pastikan tidak sedang digunakan oleh aplikasi yang lain.

Setelah server dijalankan, langkah selanjutnya adalah melakukan kegiatan chatting. Untuk memulai kegiatan chatting, user dapat memilih dan membuka form menu "Client" sehingga akan tampil form client seperti Gambar 5.

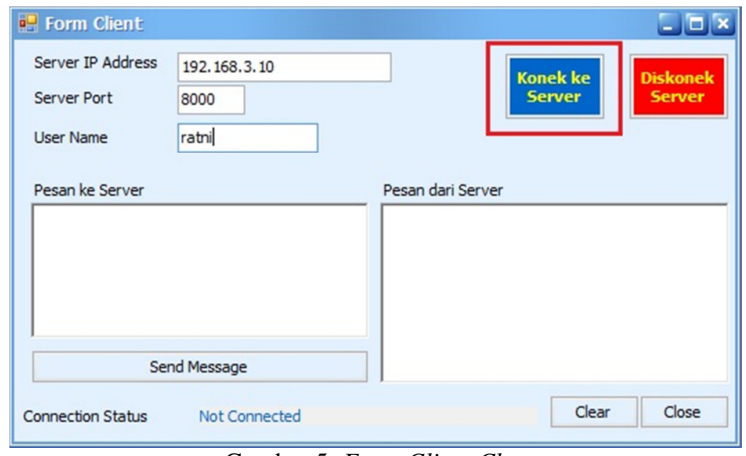

Gambar 5: Form Client Chat

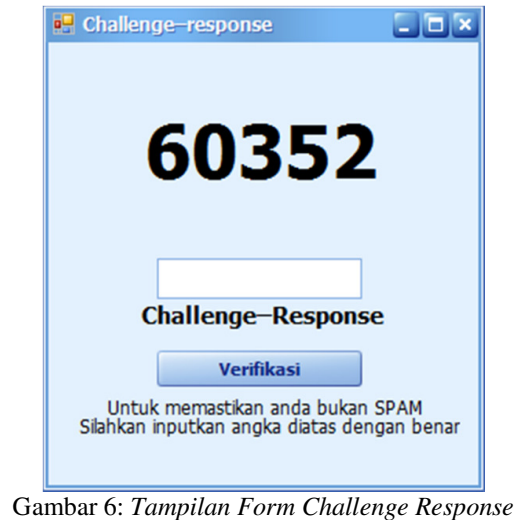

Untuk mengirimkan pesan ke server, atau ke client yang lainnya, cukup mengisi pesan kemudian menekan tombol send message. Jika proses dan koneksi sudah benar, pesan yang dikirimkan oleh client akan diterima oleh server. Apabila pesan chat yang dikirimkan oleh client memiliki nilai IDF lebih kecil dari nilai threshold maka pesan akan diklasifikasikan sebagai pesan spam, maka sistem akan langsung memumculkan form Challenge Response. Tampilan untuk form Challenge Response seperti pada Gambar 6.

Data training yang digunakan sebanyak 1224 kalimat pesan di-load melalui sistem. Tahap awal akan dihitung jumlah kata yang menyusun masing - masing kalimat (kolom "Jumlah Kata") dan jumlah kata spam yang terdapat pada masing masing kalimat (kolom "Jumlah Kata Spam"). Selanjutnya menghitung frekuensi kemunculan kata spam di dalam kalimat atau $t f$ untuk masing - masing kalimat dengan menggunakan persamaan (3) sehingga diperoleh hasil seperti Tabel 4:

TABEL IV

HASIL PERHITUNGAN DATA LATIH

\begin{tabular}{|c|c|c|c|c|c|}
\hline ID & Kalimat Asli & $\begin{array}{c}\text { Jml } \\
\text { Kata }\end{array}$ & $\begin{array}{c}\text { Filter Verb } \\
\text { Dasar }\end{array}$ & $\begin{array}{c}\text { Jml } \\
\text { Kata } \\
\text { Spam } \\
\end{array}$ & $t f$ \\
\hline 1 & $\begin{array}{l}\text { It will stop on } \\
\text { itself. I however } \\
\text { suggest she stays } \\
\text { with someone that } \\
\text { will be able to } \\
\text { give ors for every } \\
\text { stool. }\end{array}$ & 22.00 & $\begin{array}{l}\text { will } \\
\text { suggest stays } \\
\text { will able } \\
\text { give ors } \\
\text { stool }\end{array}$ & 0.00 & 0.00 \\
\hline 2 & $\begin{array}{l}\text { You have } 1 \text { new } \\
\text { message. Please } \\
\text { call } \\
\text { 08718738034. }\end{array}$ & 8.00 & $\begin{array}{l}\text { new } \\
\text { message call } \\
\text { 08718738034 }\end{array}$ & 2.00 & 0.25 \\
\hline 3 & $\begin{array}{l}\text { U r too much } \\
\text { close to my heart. } \\
\text { If u go away } i \text { will } \\
\text { be shattered. Plz } \\
\text { stay with me. }\end{array}$ & 20.00 & $\begin{array}{l}\text { Ur close } \\
\text { heart } u \\
\text { away will } \\
\text { shattered } \mathrm{Plz} \\
\text { stay }\end{array}$ & 0.00 & 0.00 \\
\hline 4 & $\begin{array}{l}\text { URGENT! We are } \\
\text { trying to contact } \\
\text { U. Todays draw } \\
\text { shows that you } \\
\text { have won a } £ 800 \\
\text { prize } \\
\text { GUARANTEED. } \\
\text { Call } \\
\text { 09050001808 } \\
\text { from land line. } \\
\text { Claim M95. } \\
\text { Valid12hrs only }\end{array}$ & 27.00 & $\begin{array}{l}\text { URGENT } \\
\text { trying } \\
\text { contact } U \\
\text { Todays draw } \\
\text { shows win } \\
\text { £800 prize } \\
\text { GUARANTEE } \\
\text { D Call } \\
\text { 09050001808 } \\
\text { land line } \\
\text { Claim M95 } \\
\text { Valid12hrs } \\
\text { only }\end{array}$ & 5.00 & 0.19 \\
\hline 5 & $\begin{array}{l}\text { I got lousy sleep. I } \\
\text { kept waking up } \\
\text { every } 2 \text { hours to } \\
\text { see if my cat } \\
\text { wanted to come } \\
\text { in. I worry about } \\
\text { him when its cold } \\
:(\end{array}$ & 28.00 & $\begin{array}{l}\text { lousy sleep } \\
\text { keep waking } \\
2 \text { hours see } \\
\text { cat wanted } \\
\text { come worry } \\
\text { cold }\end{array}$ & 2.00 & 0.07 \\
\hline$\cdots$ & $\cdots$ & $\ldots$ & $\ldots$ & $\cdots$ & $\cdots$ \\
\hline 1224 & $\begin{array}{l}\text { Ah poop. Looks } \\
\text { like ill prob have } \\
\text { to send in my } \\
\text { laptop to get fixed } \\
\text { cuz it has a gpu } \\
\text { problem }\end{array}$ & 21.00 & $\begin{array}{l}\text { Ah poop } \\
\text { Looks ill } \\
\text { prob } \\
\text { laptop fixed } \\
\text { cuz gpu } \\
\text { problem }\end{array}$ & 0.00 & 0.00 \\
\hline \multicolumn{5}{|c|}{ Nilai Rata - Rata } & 0.10 \\
\hline
\end{tabular}

Ni Luh Ratniasih: Penerapan Text Mining dalam ... 
Selanjutnya menghitung inverse frekuensi dokumen (dalam hal ini kalimat) yang mengandung kata spam atau nilai $I D F$ dengan menggunakan persamaan (4) :

$$
\begin{aligned}
I D F & =\log _{2}\left(\frac{D}{d f}\right) \\
& =\log _{2}\left(\frac{1224}{921}\right) \\
& =\log _{2}(1.33) \\
& =0.12
\end{aligned}
$$

Setelah memperoleh nilai $t f$ dan $I D F$ selanjutnya akan dihitung nilai ambang bobot $(W)$ dengan menggunakan persamaan (2), namun untuk memperoleh nilai ambang bobot $(W)$ yang akan dihitung adalah nilai rata - rata bobot $(W)$ sebagai berikut :

$$
\begin{aligned}
\bar{W}_{d, t} & =\overline{t f}_{d, t} * I D F \\
& =0.10 * 0.12 \\
& =0.012
\end{aligned}
$$

Jadi nilai ambang bobot ( $W$ ) yang digunakan untuk filtering pesan chat adalah adalah 0.012. Pesan chat dapat dikatakan spam jika bobot $(W)$ keterhubungan kata spam dengan kalimat dari pesan chat tersebut lebih besar dari nilai ambang (threshold) batas demikian sebaliknya. Sehingga dapat dibuatkan tabel klasifikasi spam dan non spam seperti Tabel 5 berikut ini :

TABEL V

KLASIFIKASI PESAN

\begin{tabular}{|l|l|}
\hline \multicolumn{1}{|c|}{ Nilai Bobot $(W)$} & Klasifikasi \\
\hline$\geq 0.012$ & Spam \\
\hline$<0.012$ & Non Spam \\
\hline
\end{tabular}

Hasil penghitungan bobot (W) pada sistem dapat dilihat pada Gambar 7.

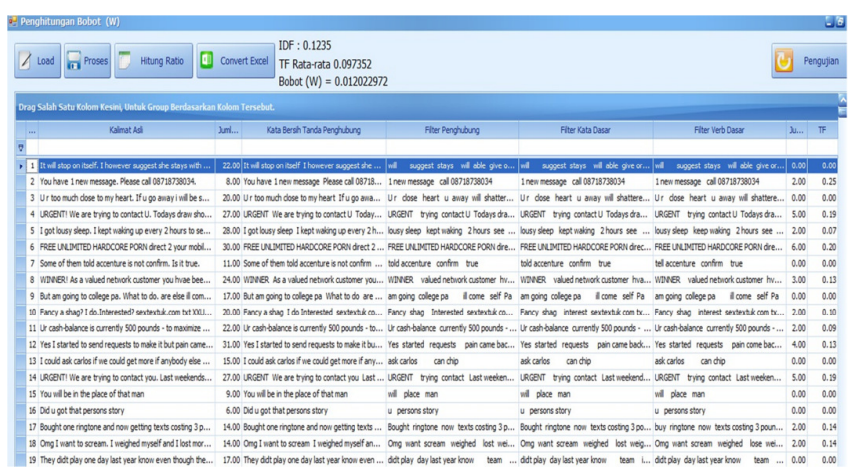

Gambar 7: Hasil Penghitungan Bobot Sistem

Jumlah data testing yang digunakan adalah sebanyak 524 kalimat pesan. Pengujian ini bertujuan untuk mendapatkan akurasi sistem dan response time.
TABEL VI HASIL PENGUJIAN

\begin{tabular}{|c|c|c|c|c|c|c|}
\hline ID & $\begin{array}{c}\text { Jumlah } \\
\text { Kata }\end{array}$ & $\begin{array}{c}\text { Jumlah } \\
\text { Kata } \\
\text { Spam }\end{array}$ & $\boldsymbol{t f}$ & $\begin{array}{c}\text { Bobot } \\
(W)\end{array}$ & Label & Hasil \\
\hline 1 & 12.00 & 0.00 & 0.00 & 0.000 & Spam & Non Spam \\
\hline 2 & 13.00 & 0.00 & 0.00 & 0.000 & Spam & Non Spam \\
\hline 3 & 18.00 & 2.00 & 0.11 & 0.299 & Non Spam & Spam \\
\hline 4 & 19.00 & 2.00 & 0.11 & 0.266 & Non Spam & Spam \\
\hline 5 & 4.00 & 0.00 & 0.00 & 0.000 & Non Spam & Non Spam \\
\hline 6 & 22.00 & 1.00 & 0.05 & 0.112 & Spam & Spam \\
\hline 7 & 25.00 & 3.00 & 0.12 & 0.254 & Spam & Spam \\
\hline 8 & 14.00 & 1.00 & 0.07 & 0.141 & Non Spam & Spam \\
\hline 9 & 22.00 & 1.00 & 0.05 & 0.097 & Non Spam & Spam \\
\hline 10 & 15.00 & 3.00 & 0.20 & 0.374 & Spam & Spam \\
\hline 11 & 21.00 & 3.00 & 0.14 & 0.255 & Non Spam & Spam \\
\hline 12 & 13.00 & 2.00 & 0.15 & 0.266 & Non Spam & Spam \\
\hline 13 & 23.00 & 3.00 & 0.13 & 0.224 & Spam & Spam \\
\hline 14 & 7.00 & 2.00 & 0.29 & 0.487 & Non Spam & Spam \\
\hline 15 & 17.00 & 0.00 & 0.00 & 0.000 & Non Spam & Non Spam \\
\hline$\cdots$ & $\ldots$ & $\ldots$ & $\ldots$ & $\ldots$ & $\ldots$ & $\ldots$ \\
\hline 524 & 8.00 & 0.00 & 0.00 & 0.000 & Non Spam & Non Spam \\
\hline
\end{tabular}

Kalimat pesan dengan ID 1 dengan kalimat "Latest News! Police station toilet stolen, cops have nothing to go on!" menunjukkan hasil bahwa jumlah kata yang terhitung sebanyak 12 kata, jumlah kata spam yang muncul pada kalimat tersebut adalah 0 , nilai $t f$ yang dihasilkan 0 , nilai bobot $(W)$ adalah 0 . Karena nilai bobot $(W)$ lebih kecil dari 0.012 maka hasil yang muncul pada kolom "Hasil" adalah Non Spam.

Confucion matrix digunakan untuk pengukuran efektifitas klasifikasi atau tingkat akuasi dengan menggunakan persamaan (1). Confucion matrix untuk membandingkan hasil proses sistem dengan label data testing ditunjukkan pada Tabel 4. Dari tabel diperoleh nilai $T P=315, T N=164, F P=$ $40, F N=5$.

TABEL VII CONFUSION MATRIX

\begin{tabular}{|c|c|c|c|}
\hline \multicolumn{2}{|c|}{} & \multicolumn{2}{c|}{ Kelas Prediksi } \\
\cline { 3 - 4 } \multicolumn{2}{|c|}{} & Spam & Non Spam \\
\hline \multirow{2}{*}{$\begin{array}{c}\text { Kelas } \\
\text { Sebenarnya }\end{array}$} & Spam & 315 & 5 \\
\cline { 2 - 4 } & Non Spam & 40 & 164 \\
\hline
\end{tabular}

Tingkat akurasi sesuai Table 7 confucion matrix yang dinyatakan dalam persamaan (1) sebagai berikut :

$$
\begin{gathered}
\text { Akurasi }=\frac{T P+T N}{T P+F N+F P+T N} * 100 \% \\
=\frac{315+164}{315+5+40+164} * 100 \% \\
=\frac{479}{524} * 100 \% \\
=91.41 \%
\end{gathered}
$$

p-ISSN:1693 - 2951; e-ISSN: 2503-2372

Ni Luh Ratniasih: Penerapan Text Mining dalam ... 
Dari 524 data testing diperoleh akurasi kecocokan antara hasil proses sistem menggunakan text mining dengan label data testing sebesar $91.41 \%$. Hasil akurasi sistem dapat juga dihitung langsung oleh sistem dengan hasil seperti Gambar 8.

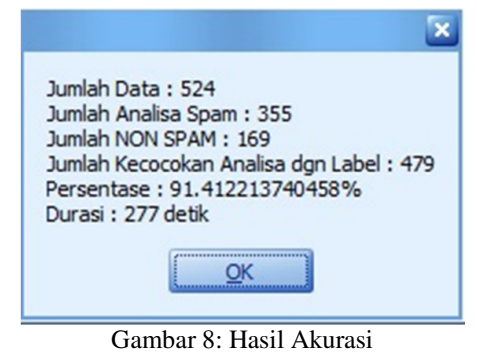

Jumlah data yang di-load sebanyak 524 kalimat pesan. Dari 524 kalimat pesan tersebut, terdapat kalimat pesan yang dinyatakan spam yaitu sebanyak 355 sedangkan non spam sebanyak 169. Jumlah kecocokan hasil proses sistem menggunakan text mining dengan label data testing sebanyak 479 kalimat pesan. Persentase kecocokan antara hasil proses sistem menggunakan text mining dengan label data testing atau dengan istilah tingkat akurasi sistem sebesar $91.41 \%$. Sedangkan respons time (waktu tanggap) yang dalam sistem disebut durasi adalah 277 detik.

\section{KESIMPULAN}

Berdasarkan hasil penelitian dapat disimpulkan beberapa hal sebagai berikut:

a. Penerapan metode text mining dan teknik challengeresponse filtering pada proses filtering pesan spam dilakukan dengan membangun sistem aplikasi chat. Proses filtering dilakukan dengan tahap text preprocessing dan analyzing sehingga diperoleh kalimat yang dinyatakan sebagai kalimat spam adalah berdasarkan kemunculan kata spam dalam kalimat pesan tersebut, dimana jika nilai $\mathrm{W}$ sebuah kalimat pesan lebih besar dari 0.012 (threshold). Pola kalimat yang dinyatakan spam adalah kalimat yang mengandung unsur seksual, kalimat yang mengandung angka yang panjang (seperti nomor telepon dan alamat), serta kalimat yang mengandung kata - kata yang tidak umum atau berbentuk singkatan.

b. Dari hasil pengujian data testing sejumlah 524 kalimat pesan diperoleh tingkat akurasi sistem sebesar $91.41 \%$. Sedangkan response time dari sistem filtering spam dalam mengklasifikasikan pesan ke dalam kelompok spam dan non spam adalah sebesar 277 detik. Faktor yang mempengaruhi tingkat akurasi adalah pertama, jumlah kata (list spam) di dalam database yang digunakan sebagai acuan kata spam, faktor kedua adalah kurangnya filtering terhadap data testing menggunakan pola kalimat spam yang telah diperoleh.

\section{REFERENSI}

[1] Abdul Kadir \& Terra CH Triwahyuni. 2003. Pengenalan Sistem Informasi. Yogyakarta: Penerbit Andi Yogyakarta.

[2] Wahyuni Diny \& Susetyo Hadi. 2008. Pengembangan Aplikasi Pertukaran Pesan Berbasis Teks Melalui Jaringan Lokal (LAN) Menggunakan Microsoft Visual C++ 6.0. Jurnal Komputasi. 2008; 07.

ISSN $1693-2951$
[3] Gomez Jose Maria, Guillermo Cajigas Bringas, Enrique Puertas Sanz. 2007. Content Based SMS Spam Filtering.

[4] Kristina Paskianti. 2011. Klasifikasi Dokumen Tumbuhan Obat menggunakan Algoritma KNN Fuzzy. Thesis Fakultas Matematika dan Ilmu Pengetahuan Alam IPB. Bogor.

[5] I. H. Witten, E. Frank, and M. A. Hall. 2011. Data Mining Practical Machine Learning Tools and Technique. Burlington: Morgan Kaufmann Publisher.

[6] Pramitarini, Y., Purnama I.K.E., Purnomo, M., 2005. Analisa Rekam Medis Untuk Menentukan Status Gizi Anak Balita Menggunakan Naive Bayes Classifier. Seminar Nasional Manajemen Teknologi XVII. Surabaya. 2 Februari 2013; ISBN:978-602-97491-6-8.

[7] Feldman, R \& Sanger, J. 2007. The Text Mining Handbook: Advanced Approaches in Analyzing Unstructured Data. Cambridge University Press: New York.

[8] Weiss, S.M., Indurkhya, N., Zhang, T., Damerau, F.J. 2005. Text Mining : Predictive Methods fo Analyzing Unstructered Information. Springer: New York.

[9] Berry, M.W. \& Kogan, J. 2010. Text Mining Aplication and theory. WILEY : United Kingdom.

[10] Dragut, E., Fang, F., Sistla, P., Yu, S. \& Meng, W. 2009. Stop Word and Related Problems in Web Interface Integration. http://www.vldb.org/pvldb/2/vldb09-384.pdf. Diakses tanggal 8 Desember 2013.

[11] Tala, Fadillah Z. 2003. A Study of Stemming Efects on Information Retrieval in Bahasa Indonesia. Institute for Logic, Language and ComputationUniversiteit van Amsterdam The Netherlands. http://www.illc.uva.n1/Research/Reports/MoL-2003-02.text.pdf. Diakses tanggal 29 September 2014

[12] Robertson, Stephen, Understanding Inverse Document Frequency: On theoretical arguments for IDF, Journal of Documentation, Vol. 60, pp. $502-520$ 